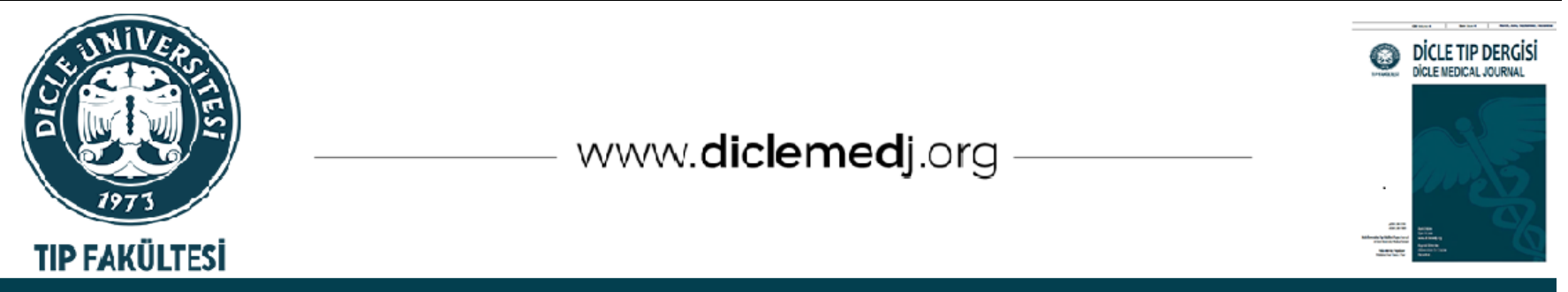

Derleme / Review

\title{
Covid 19 Hastalığı Süreci ve Çocuk Cerrahisi
}

\author{
Bahattin Aydogdu ${ }^{D}$, M.Hanifi Okur ${ }^{1} 1$ \\ 1 Dicle Üniversitesi Tıp Fakültesi Çocuk cerrahisi AD. Diyarbakır, Türkiye \\ Geliș: 23.09.2021; Kabul Tarihi: 29.09.2021
}

Öz

Covid19 pandemisinin bașlamasından beri, tüm dünyada olduğu gibi ülkemiz ve hastanemizde de hastalarla direk temas durumundaki sağlık çalışanlarını çok etkilemiştir.Özellikle virüs yükü fazla olan organlara müdahale gereği olan cerrahi branşların,preop, perop ve postop sürecinde yapılması gereken önlemleri için birçokkılavuz yayınlanmıştır. Bizim çalışmamızda dabu süreçte çocuk cerrahi ve organ nakli kliniğinde yapılması gereken ve yapılanlar hakkında güncel bilgileri paylaşmayı amaçladık.

Anahtar kelimeler:covid - çocuk cerrahisi - takip

\section{COVID 19 Disease Process and Pediatric Surgery}

\section{Abstract}

Since the beginning of the Covid19 pandemic, it has greatly affected healthcare professionals who are in direct contact with patients in our country and in our hospital, as well as all over the world.

Many guidelines have been published for the precautions to be taken during the preoperative, perop and postoperative periods, especially in surgical branches that need to intervene in organs with high viral load. In our study, we aimed to share up-to-date information about what needs to be done, and what has been done in the pediatric surgery and organ transplant clinic in this process.

Keywords: covid - pediatric surgery - follow-up.

DOI:10.5798/dicletip.1005219

YazışmaAdresi / Correspondence: Bahattin Aydogdu,Dicle Üniversitesi Tıp Fakültesi Çocuk cerrahisi AD. Diyarbakır, Türkiye e-mail: bahattinaydogdu@hotmail.com 


\section{GíRiş}

Dünyada sağlık sektöründe yeni koşullara uyum sağlanır iken, Covid 19 ve gelişen mutasyonlarının olmasıyla, virüsün tespit , yayılması vetedavisi ileilgiliyaklaşımız da ciddi değişiklere yol açmaktadır.Bu virüsün özellikle kapalı, kalabalık ortamda taşıyıcı ve enfekte kişiler tarafında hava yolu veya solunum yolu ile aerosel iletimi yoluyla yayılma potansiyeli sahip olduğu için ${ }^{1}$ Ameliyathane ve yoğun bakım gibi ekip ve temasın önemli olduğu yerlerde daha ciddi problemlere yol açabilir.Çocuk cerrahisindeki Acil veyarı acil cerrahiler olarak kabul edilen,doğumsal anomalileri olan yeni doğanlar, kanserli çocuklar, travma, malrotasyon, testis torsiyonu, apandisit ve hastalarımızın yaşadığı diğer tüm cerrahi acillerin bakımını yapmaya devam etmeliyiz.Her ne kadar COVID-19 hastalarının cerrahi sonuçlarına ilişkin mevcut klinik verilerin az olmasına rağmen sağllk personeline maruziyeti en aza indirmek ve artan perioperatifmorbidite ve mortaliteyi önlemek için ameliyat olan her hastayı vaka bazında incelemeye devam etmek çok önemlidir². Buhastaların ameliyatında, ameliyat sonrası yoğun bakım ve hastanede yatışı sürecindecovid 19pandemisinin neden olacağı problemler genellikle asemptomatik seyir eden çocuk grubu ile uğraşan çocuk cerrahları için hala önemli bir problem olarak devam etmektedir.

Çocukların yetişkinlerden farklı olarak klinik araştırma ve tedavi hakkında yeterli verinin olmamasından dolayı, tedavi algoritmaları hakkında ciddi problemler olmaktadır. Çocuklar hakkında yapılan az verili bir çalışmada $(n=10)$, negatif nazal ve faringeal RT-PCR ve semptomların çözülmesine rağmen COVID-19 virüsünün pediatrik hastaların gastrointestinal sisteminde semptomların başlamasından sonra 16 gün boyunca kalabileceğini göstermiştir33.
Kesin öneriler açılkanmamasına rağmen, Bu çalışma ile cerrahi müdahale gerektirenCovid 19 lı hastalarla ilgilenen çocuk cerrahları için ciddi zorluklar olduğunu göstermektedir.Bütün bunlar değerlendirildiğinde, yüksek volümlü hasta bakan ve cerrahisini yapan Dicle Üniversitesi Tıp Fakültesi Çocuk cerrahisi kliniğiCovid 19 salgını sırasında hastalara kendi yaklaşımınıpaylaşarak, tedavi sürecinde ve sonrasinda cocuk cerrahi hekimlerine ve çalışanlarına yardımcı olmayıamaçlamıştır.

\section{COVID VE ÇOCUKLAR}

Çocuklarda covid 19 görülme ihtimali her ne kadar az görüldüğü söylensede, aslında hemen hemen yetişkinler kadar görülmektedir. Çocuklarda asemptomatik veya hafif üst solunum yolu semptomlarıgeçirme şeklinde olduğu için bu nedenle test yaptırma ve doğrulama oranı düşük görülmektedir ${ }^{4-6}$. AmerikaCentersforDisease Control andPrevention(CDC)raporuna göre çocukların ateș, öksürük veya nefes darlığı şikayetlerin erişkinlere göre(\%73 karşı \%95) az olduğu ve çocuklarınhastaneye yatmayı gerektirme ise (\%5,7 karşı1\%10) olduğunu bildirilmiştir ${ }^{4}$. Son zamanlarda Okul çağında ve ergen çocuk grubunda Covid 19 hastalığı sonrası ateş, şok, karın ağrısı ve kalp fonksiyon bozukluğu gibi semptomlar göstererek Kawasakihastalığı ile örtüșen hiperinflamatuar sendromu ve çoklu organ yetmezliği gibi hastalıklarla başvuran vakaların artı̆̆ da rapor edilmiştir ${ }^{7,8}$.

Çinde yaplan 2135 vakalık bir çalışmada hastaların \%34 ünde PCR ile doğrulanmış \%66 şüpheli grup olarak tespit edilmiş ve bu hastaların $\% 90$ fazlasına asemptomatik, hafif ve orta düzeyde semptom olduğu görülmüştür5. ABD de Covid 19 olarak tanısinedeniyle hastaneye yatış yapılan hastaların $\% 1,6$ sı çocuk hastaları oluşmaktadır?. 
Buna rağmen yapılan çalışmalarda çocuklarda en çokgörülen semptomlar olarak ateş $(\% 64,2)$ ,öksürük $(\% 34,8)$ burun akıntısı \%16,1, dispne\%10,7 ve boğaz ağrısı\%8.9olarak rapor edilmiştir. Bir yaş altı çocuklarda disipne ön planda olur iken, Gissemptomları daha çok 10 yaş sonrası görüldüğü bildirilmiştir. Çocuklardaki radyolojik görüntülemede ray (\%35) ve CT nin \%54 oranında bulgularına rastlandığı görüldü. Laboratuardeğerlerde ise loköpenia, Trombostopenia, ALT, AST, D-Dimer ve CRPyüksekliği tespit edilmiştir ${ }^{10}$.

Son zamanlarda okul çağında veergen çocuk grubunda Covid 19 hastalığı sonrası ateş, şok, karın ağrısı ve kalp fonksiyon bozukluğu gibi semptomlar vererek Kawasakihastalı̆̆ı ile örtüşen hiperinflamatuar sendromu ve çoklu organ yetmezliği gibi hastalıklarla başvuran vakaların artığı darapor edilmiştir ${ }^{7,8}$.

\section{Covid 19 pandemisindeÇocuk cerrahisi hastasının ilk değerlendirilmesi}

Her hasta, eğer mümkünse, cerrahi öncesi COVID-19 taramasından geçmelidir. Eğer test sonucu bilinmiyorsa, hasta sanki pozitifmiş gibi cerrahi gerçekleştirilmelidir.

Çocuk cerrahisi servisine gelmeden önce Çocuk ve ebeveynleri, acil servise veya polikliniğe başvurusu esnasında COVID-19 ile ilgili ayrıntılı bir öykü alındığı ve hastanın COVID-19 açısından şüpheli veya doğrulanmış enfeksiyonunun olmadığından emin olunmalıdır. Çocukların COVID-19 enfeksiyonuasemptomatik geçirebildikleri, buna karşın ciddi düzeyde bulaştırıcı oldukları bilinmektedir. Ayrıca çocuk hastalar enfekte olmasalar bile taşıyıcı olup yüksek düzeyde bulaştırıcılık gösterebilirler. Çocuk cerrahları bu konuda özellikle dikkatli ve bilinçli olmalıdır ${ }^{11}$. Çocuk cerrahisindeki acil ve elektif vakaların sınıflandırmasını,Amerikan cerrahi kurulu tarafında sınıflandırnasın göre aşağdaki gibi sınıflandırmıştır tablo $1^{12}$.
Tablo I: Başlıca çocuk cerrahisi ameliyatlarının aciliyet durumlarına göre sınıflandırılması (ACS kllavuzundan değiștirilerek) ${ }^{12}$.

\section{a) Acil Olgular (Gecikme hayatı tehdit eder)}

1. Akut bağırsak tıkanıklığı

*Bağırsak rotasyonu anormallikleri

*İnkarsere kasık fitığı

*Hipertrofikpilorstenozu

*Radyografik redüksiyon yapılamayan invajinasyon

2. Ekstrakorporeal yaşam desteği

3. Bağırsak delinmesi

*Perfore nekrotizanenterokolit

4. Kontrolsüz kanama veya penetrasyon bulunan travma 5. İskemi

*Testis torsiyonu

*Overtorsiyonu

*Travmaya bağlı veya iyatrojenikekstremiteiskemisi

6. Doğumsal anomaliler

*Trakeoözofageal fistül ile özofagusatrezisi

*Semptomatikkonjenitaldiyafragmahernisi

*Bağırsak atrezi

*Anorektalanomaliler için stoma açılması

7. Hirschsprung hastalığı için stoma açılması (Yıkamalarla düzelmemiștir)

8. Özofageal ve trakeal yabancı cisim

b) Yarı Acil Durumlar (Günler ila haftalar arasındaki gecikmeler zararlı olabilir)

*Çoğu kanser cerrahisi, Solid tümörler

*Biliyeratrezi için portoenterostomi

*Apse insizyonu ve drenajı

*Tıbbi tedaviye yanıt vermeyen enflamatuar bağırsak hastalığının akut alevlenmesi için rezeksiyon veya stoma açılması

*Santral damaryolukateterizasyonu (kateter yerleştirme, port yerleştirme)

*Semptomatik kasık fitı̆̆ı onarımı

*Semptomatikkolelitiazis için kolesistektomi

*Dekompresyon için gerekirse gastrostomi 


\section{c) Elektif Olgular (Gecikme minimum hasta riski ile sonuçlanir)}

*Vaskülerkateterlerin çıkarılması (enfekte değil)

*Gögüs duvarı rekonstrüksiyonu

*Asemptomatik kasık fitığ

*Diversiyon

anorektalmalformasyonrekonstrüksiyonu

*Diversiyon sonrası Hirschsprung hastalığ rekonstrüksiyonu

*Diversiyon sonrası inflamatuar bağırsak hastalığı rekonstrüksiyonu

*Enterostomi kapatılması

*Meme lezyonu eksizyonu (fibroadenom)

*Brankiyal yarık kisti / sinüs eksizyonu

*Tiroglossal kanal kisti eksizyonu

*Fundoplikasyon

*Orşiopeksi

*Bariatrik cerrahi

*Hematolojik hastalık için splenektomi

*Biliyer kolik için kolesistektomi

*Asemptomatik koledok kisti onarımı

*Sünnet

Sağlık bakanlığı bilim kurulu yayınlandı̆̆ Kılavuzlara göre sadece randevulu planlanmış cerrahi işlem yapılmalıdır (acil cerrahi işlemler hariç). İşlem öncesi, işlem sırasında ve işlem sonrası personel, malzeme, yoğun bakım yatağı, servis yatağl, laboratuar ve patoloji hizmetleri planlanmalıdır. Ancak bilinci kapalı ve acil cerrahi müdahale gereken bir çocuğun öncelikli olarak COVID-19 kabul edilerek gerekli koruyucu önlemler alındıktan sonra opere edilmesi mantıklıdır ${ }^{11}$.

-Hasta tek kişilik odada yatırılmalı mümkün değil ise iki hasta arası en az bir metre mesafe olmalıdır.

-Refakatçi gerekli ise tek kişi olmalı ve COVID19 bulguları ve korunma yolları konusunda eğitim verilmelidir.
-İşlem öncesi hasta ve hasta yakını COVID-19 bulguları açısından sorgulanmalıdır.

-Cerrahi planlanan hastalarda ancak aşağıda belirtilen durumlarda COVID-19 için PCR testi yapılması gerekir.

*Tüm cerrahi branşların A grubu ameliyatları ve ilaveten baş boyun cerrahisi gerektiren hastalar

*Göğüs cerrahisi gerektiren hastalar

*Hava yolu cerrahisi planlanan hatsala

* Kanser cerrahisi planlanan hastalar ASA skoru III ve üzerinde olan ve genel anestezi gerektiren cerrahi hastalara

Pandeminin pik yaptığı dönemlerde bizim kliniğimizde bu kllavuzlar doğrultusunda elektif hastaların cerrahisi ertelendi sadece acil hastalar alındı hasta yoğunluğunun düşmesiyle.birlikteelektif hastalar kurallara uyularak bizde de alınmaya başlandı. Ayrıca vaka sayısının yüksek veya düşük olduğu dönemlerde farklı uygulamalar olmasına rağmen bölgemizde vaka sayısının yüksek olduğu pandemi dönemi boyunca hastanemizde cerrahi yapılan tüm hastalara pcr testi uygulanmış ve halen devam edilmektedir.

PCR testi planlanan tedavi/prosedür öncesi en kısa sürede yapılmalıdır. COVID -19 için PCR testi cerrahi işlemden en az 48 saat önce yapılmalıdır. İlk test sonucu negatif olanlarda,COVID-19 şüphesi yüksek ise en az 24 saat sonra ikinci testin yapılması önerilir. COVID-19 şüphesi yok ise ikinci test önerilmez. Test için örnek alınma işlemi yatan ve ayaktan hastalarda işlem yapacak birim tarafindan gerçekleştirilmeli ve sonucu takip edilmelidir. Test T.C. SAĞLIK BAKANLIĞI sonucu gelene kadar evde veya hastanede izole edilmelidir. Negatif test sonucu üzerinden 7 gün geçmeden işlem yapılmalıdır. Test sonucu pozitif çıkan hasta T.C. Sağlık Bakanlığı COVID-19 Rehberine göre yönetilir ${ }^{13}$.Test sonucu negatif olsa bile aerosol oluşturan işlemlerde N95/FFP2 maske, gözlük/yüz koruyucu ve önlük kullanılmalıdır. 
Servislerde yatan veya cerrahi işlem yaplacak hastalarda Nazogastrik sonda (NGS) yerleştirilmesi aerosol üreten işlem olarak kabul edilmelidir. Çocuk hasta COVID-19 kuşkusu olmasa bile asemptomatik taşıyıcı olabileceğinden ve işlem yüksek bulaştırıcılık riski taşıdığından, NGS takılması sırasında koruyucu önlemlerin alınması önerilir. $\mathrm{Bu}$ nedenle eğer hasta operasyona alınacaksa, NGS takılması işlemi, ameliyathanede, kişisel korunma tedbirlerini almış doktor tarafından entübasyon tamamlandıktan sonra yapılırsa daha güvenli olur. Opere edilmeyecek ve cerrahi tarafindan takip edilecek olgularda da koruyucu tedbirler uygulanır. Hasta COVID-19 kuşkulu veya tanılı ise tüm koruyucu ekipmanın giyilmesi gereklidir ${ }^{11}$.

\section{Cerrahi müdahale sırasına alınacak önlemler}

Aktif olarak sağlık sektöründe çalışanların ve özellikle cerrahi hastalarla uğraşan sağllk çalışanlarının rutin aşılamalarının gerektiği ve rapellerinin de dikkat etmeleri gerekmektedir. Çünkü İtalya da yapılan bir çalışmada sağlık çalışanların yaklaşık \%20 hastalık geçirdiği bildirilmiştir ${ }^{14}$.COVID-19 pandemisi süresince pozitif veya acil alınan hastalar için müdale odalarına da personel sayısını sınırlamak, gerek uygulayıcılar gerek ise yardımcı personelin koruyucu kıyafet, gözlük, siper, önlük ve eldiven kullanmalarıönemlidir ${ }^{15}$.

Geçmişte cerrahi dumanın birçok virüsü barındırdığı gösterilmiş olduğundan, diatermi dumanı Korona virüsün yayılımında potansiyel bir risk faktörüdür16,17. Elektrokoter ve lazer kullanımı ile oluşan dumanın tahliyesi etkin bir şekilde sağlanmalı ve bu cihazlar mümkün olan en düşük güçte çalıştırılmalıdır.Daha düşük ısıya sahip olmaları sebebiyle ultrasonik bıçaklardan kaynaklanan aerosoller konvansiyonel diatermiden kaynaklanan aerosollere kıyasla daha yüksek bir risk yaratırlar ${ }^{18}$. Olabildiğince aspiratör kullanılması önerilir.
Cerrahi ekip açısından açık cerrahi ile laparoskopik cerrahinin risk farklılıklarını ortaya koyacak net bir kanit bulunmamaktadır ${ }^{19}$. Ancak Potansiyel aerosol haline getirilmiş parçacıkların kaçışını en aza indirmek için karbondioksit filtreleyen kapalı devre cihazları kullanılmalıdır ${ }^{20}$. Karın içi basıncının mümkün olduğu kadar düşük tutulması ve trokarları almadan önce içeri verilen CO2'yi mümkün mertebe aspire edilmesi tavsiye edilir ${ }^{17,21}$. Ameliyat masasının kullanım süresini kısaltmak ve kaynakların optimum kullanımını sağlamak adına cerrahi deneyimli cerrahlarca yapılmalıdır ${ }^{21}$.

Endoskopi vebronkoskopigibi işlemler fekal,oral ve aerosolüreten bir prosedür olarak kabul edilir ve COVID-19 virüsünün bulaşması için yüksek risk olarak kabul edilmektedir. Bu hastalarıncovid testi negatif olsa bile araştırması gereken hasta grubu olarak kabul edilir ve o ciddi önlemler alınmalıdır ${ }^{2}$. Bu girişimsellerden rijit endoskopilerinfleksible endoskopiden daha yüksek bir bulaşma riski taşıdığı varsayılmaktdır.Bu girişimsellerde virüslerin bulaşma ihtimali daha yüksek olduğu için covid hastası olarak kabul edip ona göre önlem ve ekipmanlarının giyilmesi gerekiyor.

Pediatrikonkolojik hastalar agresif davranmaları nedeniyle, cerrahi müdahale de dahil olmak üzere acil tedavi gerektirtire bilinir. Bağışıklık sistemi baskılanmış kanserli çocuklarda COVID-19'un klinik özellikleri ve sonuçları hakkında şimdiye kadar sınırlı veri bulunmaktadır. Ancak Liang ve ark. Önceki pandemi deneyimlerinden (örn.,influenza A ve H1N1)varsayılarakonkolojikhastalarınCOVID19 riskini artabileceğini düşünmeketdir ${ }^{22,23}$. Yine de yeterli kanıt ve bilgi bulunmamaktadır. Daha fazla bilgi ve çalışma yapıldıkça daha net kılavuz ortaya çıkacaktır. Daha agresif seyir eden sarkomlar gibi hastalarda öncelik tanınmış ve cerrahileri yapılmış, diğerlerinde planlama daha sonra yapılmıştır ${ }^{3}$ Kliniğimizde neoadjuvankemoterapi almamış onkolojik 
cerrahi yapılmışvakalarda, onkolojiye yönlendirilmekte aile ve yakınlarına covid önlemlerinin ciddiyeti ve uyulması gereken önlemler hakkında bilgi verilmiştir. Ancak Neoadjuvankemoterapi alan vakalar preop için tekli odaya alıp personel ve hasta yakınları uyulması gereken kurallar için sıkı tembihlenmiștir.

Böbrek nakli alıcıları, SARS-CoV-2 mRNA aşılamasına yetersiz bir antikor yanıtı gösterdiği, bu daİmmünosupresyon düzeyinin önemli bir faktör olduğu söyleniyor. Mikofenolik asidin yanı sıra Takrolimus kullanımını bu yetersiz yanıtla ilişkili faktörlerdir; bunlarhücre fonksiyonunu inhibe eder ve influenza aşısına karşı antikor yanıtını doza bağlı bir şekilde etkilediği belgelenmiştir ${ }^{24,25}$.Mevcut kllavuzlar, bu popülasyonlarda aşılamanın etkinliğine ilişkin yeterli veri olmamasına rağmen, Transplant adaylarının ve alıcılarının SARS-CoV-2'ye karşı aşılanmasını önermektedir ${ }^{26}$.Organ Nakli kliniğimizde nakil yapılan alıcılara klavuzlara uygun olarak aşılamayı önermekteyiz

Resmi olarak net sonuçlar olmasa bilecovid sürecinde travmanın sayısal olarak azaldığı görülmüştür. Bununla ilgili olarak Amerikada yapılan araştırmada pandemi başlangıcından mart ve nisan aylarında acile baş vuran travma hastalrının $\% 40$ oranında azaldığını bildirmektedir ${ }^{3}$.Ancakhastanemiz 3 . Basam merkez olduğu için, ayrıca bulunduğumuz ilin pandemi süresince travmatoloji merkezi olduğu için (Devlet hastanesi pandemi hastanesi olarak kabul edilmiş) travma hastalrının sayısında çok belirgin düşme görülmedi.Nadir de olsa CovidPozitif olup cerrahi gerektiren hastalar opersayon sonrası konservati takip gerektiren hastalar ise covid yoğun bakım kliniklerine yönlendirilmiştir.

\section{Müdahale sonrasıYaklaşım}

Hastayı servise minimum sayıda personelve sağlık çalışanları eşlik ederek transferini
sağlanmalılar.Çalışanlar ameliyattan sonra, ameliyathanede kullandığı gereçleri (cep telefonu, anahtarlık gibi) uygun şekilde dezenfekte ederek evine gitmelidir. COVID-19 (+) hastada kullanılan tüm araç ve gereçler ayrı olarak dezenfekte ve sterilize edilmelidir ${ }^{11}$.

Sonuç olarak çocuk cerrahları da tüm sağlık personellerinde olduğu gibi, COVID-19 salgınında ciddi risk altındadırlar. Çocuklarda covid 19 genellikle asemptomatik seyir ettiği için cerrahi müdahale ve yoğun bakıma gerektiren acil hastaların Şüpheli veya covid pozitif olarak kabul edilmeli ve yaklaşımları kılavuzlara uygun olarak yapılmalıdır.Salgından korunmanın en önemli yolu, korunma önlemlerini çok iyi bilmek ve uygulamaktan geçmektedir. Deneyimlerimizin gelecekte COVID-19 ve diğer halk sağlı̆̆ krizleri ile benzer durumlarla karşılaşabilecek diğer çocuk hastaneleri için faydalı olabileceğini umuyoruz.

Çıkar Çatışması Beyanı: Yazarlar çıkar çatışması olmadığını bildirmişlerdir.

Finansal Destek: Bu çalışma her hangi bir fon tarafından desteklenmemiştir.

\section{Declaration of ConflictingInterests:Theauthorsdeclarethatth eyhavenoconflict of}

interest.

Financial Disclosure: No financialsupportwasreceived.

\section{KAYNAKLAR}

1. WHO Coronavirus disease (COVID-19) outbreak situation. Available at: https://www.who.int/emergencies/diseases/novelcoronavirus-2019.

2. DeFazio JR, Kahan A, Fallon EM, et al. Development of pediatric surgical decision-making guidelines for COVID-19 in a New York City children's hospital. J Pediatr Surg. 2020 Aug; 55: 1427-30. doi: 10.1016/j.jpedsurg.2020.05.043. Epub 2020 Jun 6. PMID: 32553456; PMCID: PMC7274992. 
3. Tan YP, Tan BY, Pan J, et al. Epidemiologic and clinical characteristics of 10 children with coronavirus disease 2019 in Changsha, China. 2020. J Clin Virol. 2020;127: 104353.

4. CDC COVID-19 Response Team. Coronavirus disease 2019 in children - United States, February 12-April 2, 2020. MMWR. 2020;69: 422-6.

5. Dong $\mathrm{Y}, \mathrm{Mo} \mathrm{X}, \mathrm{Hu} \mathrm{Y}$, et al. Epidemiological characteristics of 2143 pediatric patients with 2019 coronavirus disease in China. Pediatrics. 2020;145:e20200702.

6. Lu X, Zhang L, Du H, et al. SARS-CoV-2 infection in children. New Engl J Med. 2020;382: 1663-5.

7. Riphagen S, Gomez X, Gonzalez-Martinez C, et al. Hyperinflammatory shock in children during COVID19 pandemic. Lancet. 2020;395: 1607-8. YASUHARA ET AL. | 2573

8. Verdoni L, Mazza A, Gervasoni A, et al. An outbreak of severe Kawasaki-like disease at the Italian epicentre of the SARS-CoV-2 epidemic: an observational cohort study. Lancet. 2020; 395: 1771-8.

9. Centers for Disease Control and Prevention. Coronavirus Disease 2019 (COVID-19)-Associated Hospitalization Surveillance Network (COVIDNET). Updated October 10, 2020.

10. Yasuhara J, Kuno $\mathrm{T}$, Takagi $\mathrm{H}$, et al. Clinical characteristics of COVID-19 in children: A systematic review. Pediatr Pulmonol. 2020 0ct; 55: 2565-75. doi: 10.1002/ppul.24991. Epub 2020 Aug 4. PMID: 32725955.

11. Oktav Bosnall, Burak Tander COVID-19 pandemisi ve çocuk cerrahisi Review Çoc. Cer. Derg. 2020; 34:1-8 doi:10.5222/JTAPS.2020.62333

12. COVID-19 Guidelines for Triage of Pediatric Patients. 11.04.2020. Available from: https://www.facs.org/ covid-19/clinicalguidance/elective-case/pediatricsurgery

13. Covid-19 çocuk hasta yönetimi ve tedavisi. COVID19 (SARS-CoV-2 Enfeksiyonu) Rehberi. Bilim Kurulu Çalışması (13.04.2020). 14.04.2020. Available from: https://

covid19bilgi.saglik.gov.tr/depo/rehberler/COVID-19_ Rehberi.pdf

14. The Lancet. COVID-19: protecting health care workers. The Lancet. 2020;395 (10228):922.
15. Brindle M, Gawande A. Managing COVID-19 in Surgical Systems. Ann Surg 2020:1

16. Capizzi PJ, Clay RP, Battey MJ. Microbiologic activity in laser resurfacing plume and debris. Lasers Surg Med 1998;23:172-4.

17. Johnson GK, Robinson WS. Human immunodeficiency virus-1 (HIV-1) in the vapors of surgical power instruments. J Med Virol 1991;33:4750.

18. Zheng MH, Boni L, Fingerhut A. Minimally Invasive Surgery and the Novel Coronavirus Outbreak. Ann Surg 2020:1.

19. The British Association of Paediatric Endoscopic Surgery. BAPES Statement: Coronavirus (COVID-19) and endoscopic surgery. 2020.

20. Morris SN, Fader AN, Milad MP, et al. Understanding the "scope" of the problem: why laparoscopy is considered safe during the COVID 19 pandemic. The J Minim Invasive Gynecol. 2020.

21. Alex Mottrie, Stefano Puliatti, Elio Mazzone, ERUS. ERUS (EAU Robotic Urology Section) guidelines during COVID-19 emergency. 2020.

22. Kotecha RS. Challenges posed by COVID-19 to children with cancer. Lancet Oncol. 2020. https://doi.org/10.1016/S1470-2045(20)30205-9

[Epub ahead of print].

23. Liang $\mathrm{W}$, Guan $\mathrm{W}$, Chen $\mathrm{R}$, et al. Cancer patients in SARS-Co-V-2 infection: a nationwide analysis in China. Lancet Oncol. 2020;21:335-6.

24. Boey L, Curinckx A, Roelants $M$, et al. Immunogenicity and safety of the nine-valent human papillomavirus vaccine in solid organ transplant recipients and adults infected with human immunodeficiency virus (HIV). Clin Infect Dis 2020:ciaa1897. doi.org/10.1093/cid/ciaa1897. https://

25. Natori Y, Shiotsuka M, Slomovic J, et al. A doubleblind, randomized trial of high-dose vs standard-dose influenza vaccine in adult solid-organ transplant recipients. Clin Infect Dis 2018;66: 1698e704.

26. American Society of Transplantation. American society of transplantation COVID-19 vaccination guidance. 2020. Available from: https://www.myast. org/sites/default/files/ASTCOVID-info.pdf [cited 19th February 2021]. 